\title{
Study of Microstructure at Different Sintering Temperatures of Alumina Reinforced Hydroxyapatite Bioceramic Composite
}

\author{
Vaibhav Trivedi ${ }^{1}$, Anupam Srivastav ${ }^{2}$, Rahul bhatnagar ${ }^{3}$, Mohd Javed ${ }^{4}$ \\ 1,3,4 (Department of Mechanical Engineering, IFTM University Moradabad, India) \\ ${ }^{2}$ (Middle East College, Knowledge Oasis Muscat, Sultanate of Oman)
}

\begin{abstract}
Hydroxyapatite $\mathrm{Ca}_{10}\left(\mathrm{PO}_{4}\right)_{6} \cdot \mathrm{OH}_{2}$ (HAp), known for bioactive fixation with the surrounding bone tissues, is one of the most studied and used material for implants. The brittle behavior of HAp due to lower fracture toughness under mechanical loads is improved by addition of a ceramic second phase such as $\mathrm{Al}_{2} \mathrm{O}_{3}$, $\mathrm{SiC}, \mathrm{ZrO}_{2}$, etc. There is a need to focus on the microstructure of such reinforced biomaterials to understand the relationship between their established mechanical behavior and the microstructure. In this work microstructure of pure $\mathrm{HAp}$ and $20 \mathrm{wt} \% \mathrm{Al}_{2} \mathrm{O}_{3}-\mathrm{HAp}$ biocramic composite, sintered at $1050^{\circ} \mathrm{C}, 1150^{\circ} \mathrm{C}$ and $1250^{\circ} \mathrm{C}$ temperature range for 02 hours curing time, is studied to establish relationship of strengths and microstructure of these materials.
\end{abstract}

Keywords: Reinforced Hydroxyapatite, Sintering, Microstructure, SEM

\section{Introduction}

During the last decades, numerous types of biomaterial of various classes have been developed and synthesized, which either belong to metals, polymers or ceramics, category. In the metallic category of Biomaterials, Titanium alloys are commonly used as implant material, due to high fracture strength associated with their high fracture toughness [1]. As feasible alternative to metals due to many problems associated with them, Ceramic materials are used because of their chemical composition being closer to that of hard tissues, which give rise to a better biocompatibility [2,3]. Chemical composition of the mineral bone is close to that calcium phosphates and therefore maximum attention has been given to bioceramics compounds of this family [4-6].

Hydroxyapatite $\mathrm{Ca}_{10}\left(\mathrm{PO}_{4}\right)_{6} \cdot \mathrm{OH}_{2}$ (HAP), which is known for a bioactive fixation with the surrounding bone tissues, has become a most studied and used material for permanent implants. The main problem with bioceramics like hydroxyapatite is its brittle behavior due to lower fracture toughness under mechanical loads [7-10]. The addition of a ceramic second phase such as $\mathrm{Al}_{2} \mathrm{O}_{3}, \mathrm{SiC}, \mathrm{ZrO}_{2}$, etc is known to be a way to improve the mechanical reliability of ceramic matrices [11-13]. In spite of various studies having been devoted to these types of reinforcement of hydroxyapatite matrices, no study has focused on the comparison of microstructure of such reinforced materials, fabricated at different temperatures.

\section{Literature Review}

A common approach in practice with regard to preparing a stronger bioceramic based biomaterial is the use of bioceramics, whether bioactive or bioinert for its excellent biological behavior and improve the relative weak mechanical properties by reinforcement with an appropriate second phase [14]. To be effective as a reinforcing agent, for a ceramic-matrix composite material, the strength and elastic modulus of the second phase must be higher than those of the matrix [15]. In addition, the reinforcement must be chemically compatible with respect to the matrix. Moreover, the coefficient of thermal expansion of the reinforcing agent should be as close as possible to that of the matrix to avoid the formation of micro cracks around the second phase [16].

Hard bioceramic particle reinforced Hydroxyapatite composite has been investigated by many workers in which acceptable biocompatibility as well as the mechanical strength of these materials has been established. It is also known now that the mechanical properties of hydroxyapatite (HAp) bioceramic material improve significantly by adding tetragonal-zirconia-polycrystalline (TZP) powder coated with $\mathrm{Al}_{2} \mathrm{O}_{3}$. Composite containing 15 volume \% zirconia and 30 volume \% alumina, added to the HAp by the coating method shows about 3 times higher strength and the fracture toughness than those of pure HAp [17]. In similar study involving Zirconia toughened HAp composites, the elastic modulus was found to increase from $110 \mathrm{GPa}$ for pure HAp to $171 \mathrm{GPa}$ and the fracture toughness from 1.2 $\mathrm{MPa} \mathrm{m}^{1 / 2}$ to $2.1 \mathrm{MPa} \mathrm{m}^{1 / 2}$ for the composite [18].

Among the various reinforcing agents, the Alumina $\left(\mathrm{Al}_{2} \mathrm{O}_{3}\right)$ is the most widely investigated [19]. The primary role of alumina as second phase reinforcement is to prevent catastrophic brittle failure by transformation-induced retardation of grain growth and crack deflection toughening mechanism [20]. However, when this oxide is used as a reinforcing agent for HAp, the decomposition of HAp to $\beta$-TCP occurs severely, resulting in poor densification and reduced mechanical properties [21]. Therefore, efforts are being made to 
produce fully densified $\mathrm{HAp}-\mathrm{Al}_{2} \mathrm{O}_{3}$ composites without the decomposition. The desired property of osteo conductivity remains the dominating effect in these HAp composite materials [22].

Further, it has been reported that the particle size of these reinforcements are the major factor affecting the mechanical properties. When large alumina platelets are added, the improvement in strength is minimal because of formation of micro cracks around the platelets due to large difference in coefficient of thermal expansion between $\mathrm{HAp}$ and $\mathrm{Al}_{2} \mathrm{O}_{3}$. On the other hand, when fine $\mathrm{Al}_{2} \mathrm{O}_{3}$ was used as reinforcements, the strength improved steadily with increasing amount of $\mathrm{Al}_{2} \mathrm{O}_{3}$ [23].

In all such studies, major emphasis has been given to the phases present and mechanical property improvements. Not much work is found which gives the the comparison of the microstructure of Alumina-HAp biocermics composite to correlates with the reported mechanical improvements. This work establishes these relationships of microstructure of bioceramic composite with the sintering temperatures which in turn have direct relations with the strengths. For this study $20 \mathrm{wt} \% \mathrm{Al}_{2} \mathrm{O}_{3}-\mathrm{HAp}$ composite has been selected, based on reports of work [24-25] in which compositions ranging from $10 \mathrm{wt} \%$ to $40 \mathrm{wt} \%$ have been investigated over $1050^{\circ} \mathrm{C}$ to $1250^{\circ} \mathrm{C}$ temperature range.

\section{Materials And Methods}

Raw materials used for the study were analytical grade reagents and chemicals (99\% pure). The raw materials used are:

3.1 Hydroxyapetite $\left\{\mathrm{Ca}_{10}\left(\mathrm{PO}_{4}\right)_{6}(\mathrm{OH})_{2}\right\}$

The matrix material for the different composite materials prepared and investigated was pure and synthetic hydroxyapatite (HAp) (Fisons, Philadelphia, USA make having 502.32 as Molecular Weight. The particle size of the powder was in the range of $0.5 \mu \mathrm{m}$ to $2.0 \mu \mathrm{m})$.

\subsection{Alumina $\left(\mathrm{Al}_{2} \mathrm{O}_{3}\right)$}

For preparation of $20 \mathrm{wt} \%$ alumina-HAp composites, $\alpha-\mathrm{Al}_{2} \mathrm{O}_{3}$ powder (Merc, Germany, having particle size $<20 \mu \mathrm{m}$ ) was taken as reinforcing particles.

\subsection{Polyvinyl Alcohol}

It was procured from C.D.H., New Delhi, and used as an organic binder for the compaction of the powders.

\section{Specimen Preparation And Sintering}

For the micro structural studies involving the selected materials, one composition containing pure Hydroxyapatite and other containing $20 \mathrm{wt} \%$ Alumina-Hydroxyapatite composite were prepared by first mixing the powder well in agate mortar in presence of acetone for 3 hours. $2 \mathrm{wt} \%$ of PVA was added as binder to this powder and the mixture was again mixed for 1 hour. The thoroughly mixed powders having different compositions were then compacted in a rectangular die under a hydraulic press at pressure $25 \mathrm{KN} / \mathrm{cm}^{2}$. All the specimens were prepared in a shape of rectangular bar of dimension $25 \mathrm{~mm}$ x $5 \mathrm{~mm}$ x $3 \mathrm{~mm}$. These green specimens were then sintered at $1050^{\circ} \mathrm{C}, 1150^{\circ} \mathrm{C}$ and $1250^{\circ} \mathrm{C}$ in a microprocessor controlled programmable super kanthal furnace (Eurotherm P818 programmable temperature controller Baishakh \& Co. Ltd., Calcutta) maintaining $07^{\circ} \mathrm{C} / \mathrm{min}$ heating and cooling rates, and keeping a curing time of 2 hours at each temperature.

\subsection{Xrd And Microstructural Analysis}

All the different composites to be investigated in this study as well as pure HAp, pure alumina, all sintered at different temperatures (along with un-sintered starting powders of pure HAp, alumina, 20\% alumina-HAp mixture) is characterized for phase identification using XRD. For the study of type of microstructure and size and distribution of pores, etc., the sintered as well as fractured samples of each type (without polishing the surface) were examined under SEM. All the samples were coated with Gold-Palladium film to improve its electron conductivity during Scanning Electron Micrographs.

\section{Results And Discussion}

The Scanning Electron Microscopy (SEM) was done to analyze the microstructure of pure HAp as well $20 \mathrm{wt} \%$ alumina-HAp composites specimens, sintered at $1050^{\circ} \mathrm{C}, 1150^{\circ} \mathrm{C}$ and $1250^{\circ} \mathrm{C}$ temperature for the 02 hours curing time, studying both, the sintered surface and the fractured surface of each specimen. The SEM micrographs of these specimens are shown in Figure 1 to Figure 12. Figure 1 to Figure 3 shows sintered surface of pure HAp specimens sintered for $02 \mathrm{hrs}$ at the three selected temperatures. These micrographs reveal that good sintering is achieved even at $1050^{\circ} \mathrm{C}$, which increases at $1250^{\circ} \mathrm{C}$. However, at $1250^{\circ} \mathrm{C}$, irregular surface with bubble like structures is visible, which is indicator of decomposition of HAp (as confirmed through XRD given in Figure 18), as has also been reported in such previous work by other authors, mentioned in literature 
review. The fractured surfaces of these specimens given in Figure 4 to Figure 6 do not show any cracks or pores within the specimen at lower temperature of $1050^{\circ} \mathrm{C}$. But at $1150^{\circ} \mathrm{C}$ and $1250^{\circ} \mathrm{C}$ well distributed network of pores is seen, which correlates well with decrease in strength of HAp at higher temperatures reported in other work [25-27].

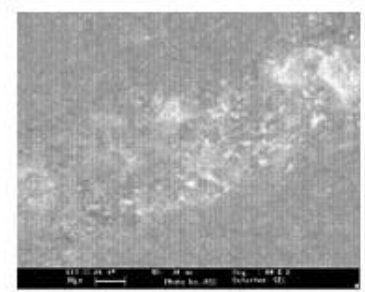

Figure 1

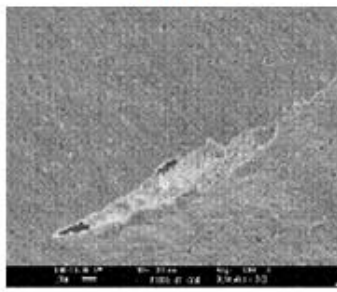

Figure 4

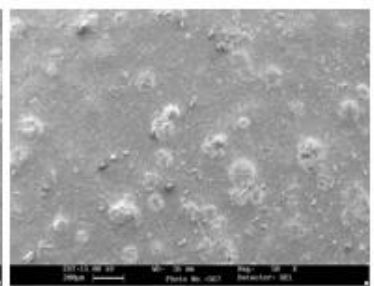

Figure 2

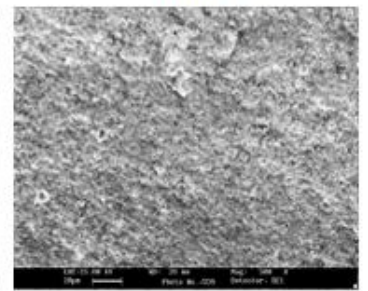

Figure 5

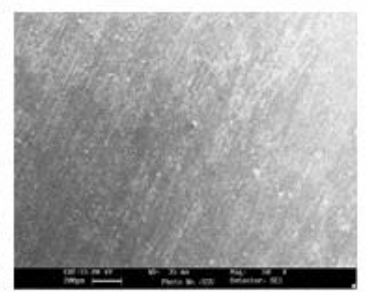

Figure 3

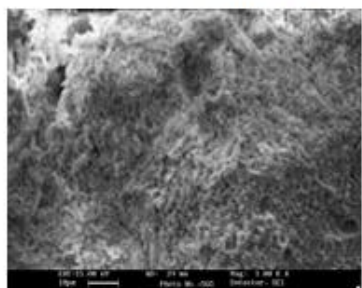

Figure 6

Figure 1-3: Sintered surface of pure HAp at $1050{ }^{\circ} \mathrm{C}, 1150{ }^{\circ} \mathrm{C}$ and $1250{ }^{\circ} \mathrm{C}$ respectively; Figure 4-6 Fractured surface of pure $\mathrm{HAp}$ at $1050{ }^{\circ} \mathrm{C}, 1150{ }^{\circ} \mathrm{C}$ and $1250{ }^{\circ} \mathrm{C}$ respectively;

Figure 7- 9 shows dense $\mathrm{Al}_{2} \mathrm{O}_{3}$-HAp composite sintered at the three selected temperatures. In case of specimen sintered at $1250{ }^{\circ} \mathrm{C}$ too, well pronounced surface cracks are visible across the surface. These cracks are due to decomposition of HAp and formation of Calcium Aluminates as confirmed by XRD shown in Figure 21.

The internal microstructure revealed in the SEM of fractured surfaces of $\mathrm{Al}_{2} \mathrm{O}_{3}$-HAp composite sintered at $1050{ }^{\circ} \mathrm{C}, 1150{ }^{\circ} \mathrm{C}, 1250{ }^{\circ} \mathrm{C}$ (Figure 10 to Figure 12) also confirms dense core with pore size less than $2-3 \mu \mathrm{m}$ in all the specimens. The fact that the pore size does not increase to any significant level even at $1250^{\circ} \mathrm{C}$ enables the $\mathrm{Al}_{2} \mathrm{O}_{3}$-HAp composite to exhibit higher strength (as reported in [25]) than compared to pure HAp at all temperature ranges. It is therefore confirmed through these micrographs that the addition of $\mathrm{Al}_{2} \mathrm{O}_{3}$ in $\mathrm{HAp}$ matrix not only strengthens the matrix but also retain small pore size even at elevated temperatures, thereby negating the effect of HAp decomposition.

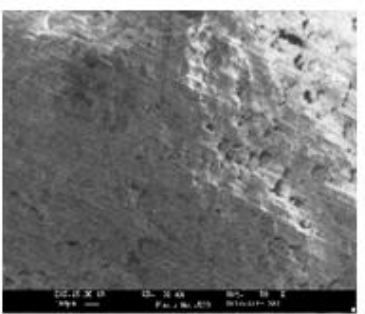

Figure 7

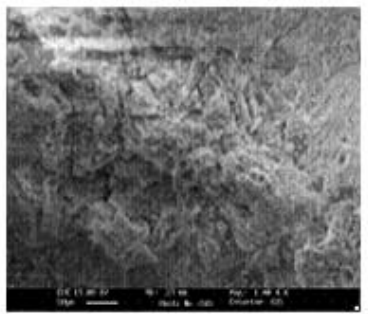

Figure 10

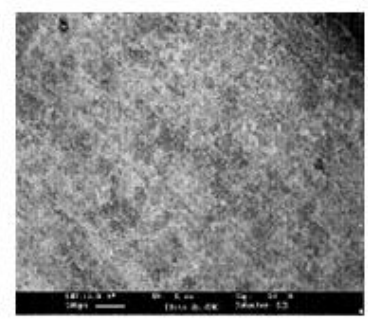

Figure 8

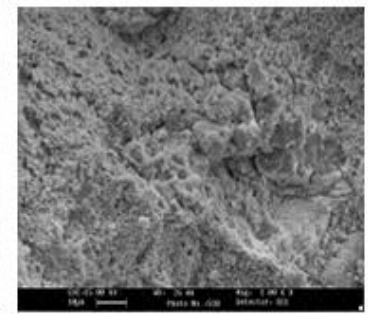

Figure 11

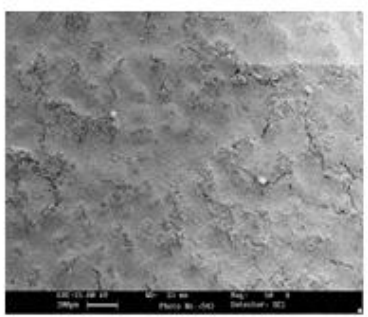

Figure 9

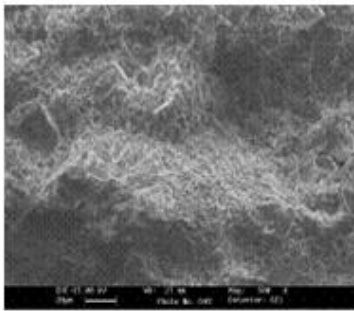

Figure 12

Figure7-9 Sintered surface of $20 \mathrm{wt} \% \mathrm{Al}_{2} \mathrm{O}_{3}-\mathrm{HAp}$ at $1050{ }^{\circ} \mathrm{C}, 1150{ }^{\circ} \mathrm{C}$ and $1250{ }^{\circ} \mathrm{C}$; Figure 10-12 Fractured surface of $20 \mathrm{wt} \% \mathrm{Al}_{2} \mathrm{O}_{3}-\mathrm{HAp}$ at $1050{ }^{\circ} \mathrm{C}, 1150{ }^{\circ} \mathrm{C}$ and $1250{ }^{\circ} \mathrm{C}$ 


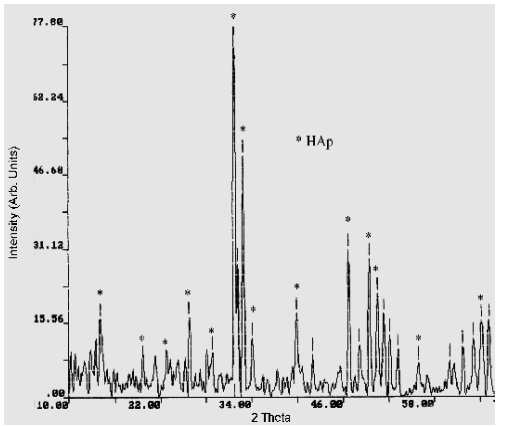

Figure 13

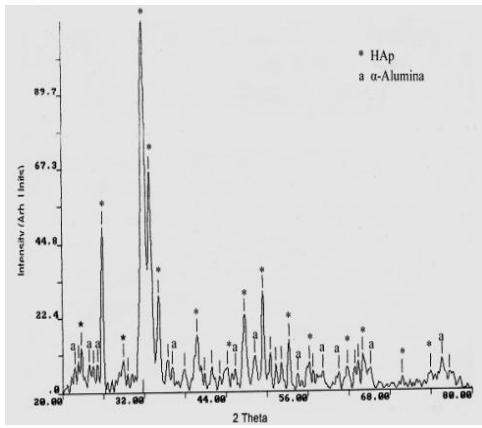

Figure 14

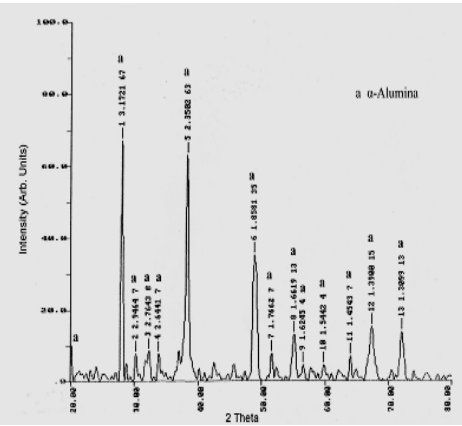

Figure 15

Figure13-15 XRD of un-sintered starting powders of pure HAp, Alumina and $20 \mathrm{wt} \% \mathrm{Al}_{2} \mathrm{O}_{3}-\mathrm{HAp}$ respectively

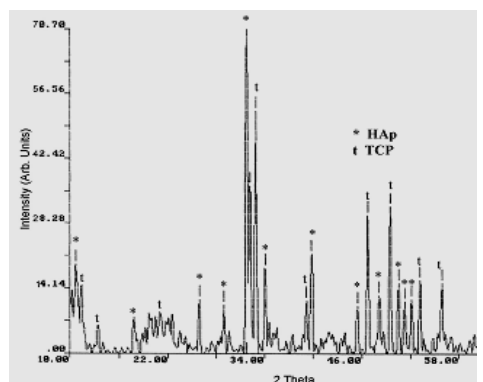

Figure 16

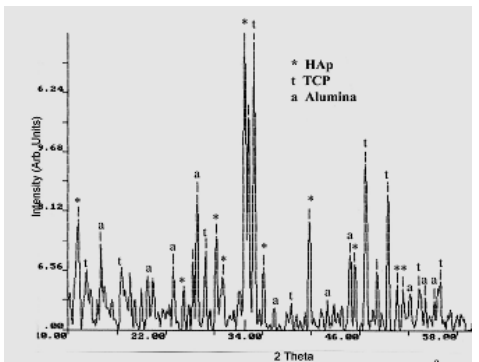

Figure 19

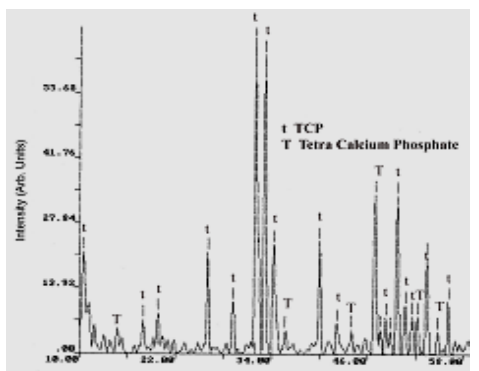

Figure 17

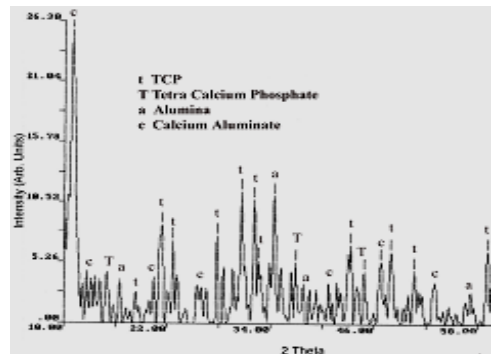

Figure 20

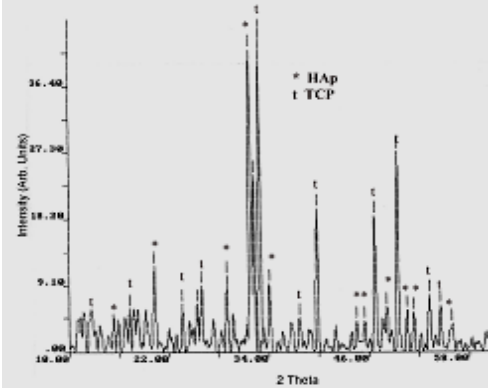

Figure 18

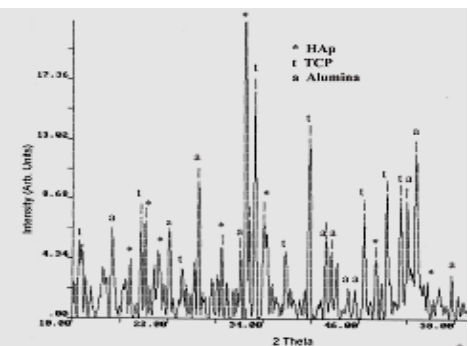

Figure 21

Figure16-18 XRD of pure HAp sintered at $1050^{\circ} \mathrm{C}, 1150^{\circ} \mathrm{C}, 1250^{\circ} \mathrm{C}$ for 02 hours respectively

Figure19-21 $\mathrm{XRD}$ of $20 \mathrm{wt} \% \mathrm{Al}_{2} \mathrm{O}_{3}-\mathrm{HAp}$ composite sintered at $1050^{\circ} \mathrm{C}, 1150^{\circ} \mathrm{C}, 1250^{\circ} \mathrm{C}$ for 02 hours respectively.

\section{Conclusion}

The microstructural studies using SEM, carried out on pure $\mathrm{HAp}$ and $20 \mathrm{wt} \% \mathrm{Al}_{2} \mathrm{O}_{3}-\mathrm{HAp}$ composite sintered at $1050^{\circ} \mathrm{C}, 1150^{\circ} \mathrm{C}, 1250^{\circ} \mathrm{C}$ temperatures for 02 hours curing time establishes that the decomposition of pure $\mathrm{HAp}$ at higher temperature $\left(1250^{\circ} \mathrm{C}\right)$ leads to formation of rough and irregular sintered surface and porous internal structure, which is the reason of decrease in strength of HAp with temperature beyond $1050^{\circ} \mathrm{C}$. Also, the presence of $20 \mathrm{wt} \% \mathrm{Al}_{2} \mathrm{O}_{3}$ in $\mathrm{HAp}$ bioceramics, which is known to increase the strength, does not allow pore size in the bulk to increase in this material, thereby showing higher strengths compared to pure $\mathrm{HAp}$ and $\mathrm{Al}_{2} \mathrm{O}_{3^{-}}$ HAp composites sintered at lower temperatures.

\section{References}

[1]. D. I. Bardos, in: Concise encyclopedia of medical \& dental materials, edited by D. Williams, Pergamon Press, Oxford (1990), p. 360.

[2]. L. L. Hench: J. Amer. Ceram. Soc.74 (1991), p.1487.

[3]. G. Heimke: Adv. Ceram. Mater. 2 (1987), p.764.

[4]. K.D. Groot, in: Bioceramics of calcium phosphate', edited by K. D. Groot CRC Press, USA, (1983), p.99.

[5]. M. Jarcho: Clin. Orthop. Rel. Res.157 (1981), p.259.

[6]. R.W. Bucholz, A. Carlton and R.E. Holmes: Orthop. Clin. N. Amer. 18 (1987), p.323.

[7]. M. B. Thomas and R. H. Doremus: Ceram. Bull. 60 (1981), p. 258.

[8]. G. D. With, H. J. A. V. Dijk, N. Hattu and K. Prijs: J. Mater. Sci. 16 (1981), p.1592.

[9]. J. Li and L. Hermansson: Interceram.39 (1990), p.13. 
[10]. R. Halouni, D. Bernache-Assollant, E. Champion and A.J. Ababou: Mater. Sci.: Mater. Med. 5 (1994), p. 563.

[11]. R. W. Rice: Ceram. Engng. Sci. Proc. 2 (1981), p. 661

[12]. K. Xia and T. G. Langdon: J. Mater. Sci. 29 (1994), p.5219.

[13]. S.T. Buljan, A. E. Pasto and H. J. Kim: Ceram. Bull. 68 (1989), p.387.

[14]. P. Ducheyne: J. Biomed Mater. Res - Applied Biomaterials: 21 (A2) (1987), p. 219

[15]. H. Ji and P.M. Marquis: Biomaterials 13 (11) (1992), p.744.

[16]. D.W. Richerson: Marcel Decker Inc., (1992), p. 73.

[17]. M.Kikuchi, J.Tanaka, Y.Koyama and K.Takakuda: J. Biomed Mater. Res 48(2) (1999), p. 108.

[18]. A.A. Griffith: Philos, R. Soc. London 221(A), p.163 (1920) Trans. Am. Cer. Soc. Met., 61, reprinted in (1968), p. 871.

[19]. Y. E. Greish and P. W. Brown: J. Biomed. Mater. Res. 52 (4) (2000), p. 687.

[20]. J. Huaxia and P.M.Marquis: J. Mater. Sci.28 (1993), p.1941.

[21]. K. Kondo, M. Okuyama, M. Ogawa, and Y. Shibata: Communications J. Am. Cer. Soc. Nov. (1984), p. 222

[22]. H. W. Kim, Y. H. Koh, S. B. Seo and H. E. Kim: Mater. Sci. and Engg.23 C (2003), p. 515,

[23]. D. W. Richerson: Marcel Decker Inc. (1992), p. 731.

[24]. Srivastav: Ph.D Thesis, U.P Technical University, Lucknow, India (2006)

[25]. S. Kim, Y-M. Kong, I-S. Lee and H.E. Kin Mater. Sci.: Mater. Med., 13 (2002), p. 307.

[26]. Rapacz-Kmita, A., Slosarczyk, A., Paszkiewicz, Z.: J. of the European Ceramic Society, 26 (2006), p. 1481.

[27]. T. V. Thamaraiselvi and S. Rajeswari: Trends Biomater. Artif. Organs 18(1), (2004) p 9 